\title{
Salivary Flow Rate in Human Population with High Radon Exposure and Its Correlation to
}

\section{Caries}

\author{
Irmaleny $^{1^{*}}$, Soehardjo $^{2}$, Sri Tjahajawati ${ }^{3}$, Nisa Nadiah $^{4}$ \\ ${ }^{1}$ Department of Conservative Dentistry and Endodontics, Faculty of Dentistry, Universitas \\ Padjadjaran, Bandung 40134, Indonesia \\ ${ }^{2}$ Department of Radiology Dentistry, Faculty of Dentistry, Universitas Padjadjaran, Bandung \\ 40134, Indonesia \\ ${ }^{3}$ Department of Oral Biology, Faculty of Dentistry, Universitas Padjadjaran, Bandung 40134, \\ Indonesia \\ ${ }^{4}$ Faculty of Dentistry, Padjadjaran University, Bandung 40134, Indonesia \\ *Email: irmaleny_drg@yahoo.co.id
}

\begin{abstract}
Radon is a radioactive substance derived from a uranium compound, it is odorless and colorless. It can radiate an alfa beam which is capable of damaging the performance of the salivary gland causing decreased saliva volume. This diminishes the self-cleansing ability of the teeth and encourages the development of caries. Our method in this research was observational and a cross sectional survey was used. There were 100 samples, consisting of 50 residents from Cipatat village and 50 residents from Gunung Masigit village. The research was conducted by measuring the salivary flow rate and the prevalence of caries in the two villages. The difference in saliva flow rate between residents in the area with high radon concentration, $(0,231$ $\mathrm{ml} /$ minute $)$ and residents in the area with low radon concentration $(0.467 \mathrm{ml} / \mathrm{mi}$ nute) was significant ( $\mathrm{p}$-value $=0.000,<0.005)$. The prevalence of caries in the area with a high radon concentration (11.84) was significantly higher than that in the low radon concentration area $(7.6)(\mathrm{p}$-value $=0.000,<0.05)$. The correlation between the salivary flow rate and the prevalence of caries in the high radon content village had an $r$ value of -0.043 and a $p$-value of 0.768 . The conclusion of this research is therefore that there is no correlation between salivary flow rate and prevalence of caries in residents in the high radon concentration area.
\end{abstract}

Keywords: saliva flow rate, DMF-T, caries prevalence, radon

\section{Introduction}

Saliva plays a role in lubrication, soft tissue protection during mastication, antibacterial activity against microorganisms, and in the cleansing of the oral cavity from food scraps [1]. Saliva has the ability to prevent the occurrence of dental caries. The protein composition of saliva plays an important role in determining the etiology of caries and other oral diseases [2].

Radon is a radioactive substance, a noble gas that is widely spread in the lithosphere, and has no color, smell, or taste. Radon is the heaviest gas substance present in the normal atmosphere [3]. The radon gas in air spontaneously decays or turns into another atom. This radon decay product is electrically charged and can 
attach to dust particles and easily be inhaled, irradiating the nucleus of the cells through which it travels [4].

Humans spend $80 \%$ of their time in buildings. The presence of radon gas in buildings, such as homes, can cause a high risk of exposure to radiation. Radon is produced by the decay of the radium found in soil, rocks and water. Radon gas can easily seep into a room. The radon that irradiates the body may come through cracks in the floors and walls, and from floor surfaces in the form of soil, and from cavities inside walls and around loose pipes. In addition, radon can also enter the human body through drinking water that has been contaminated with uranium [5].

Radon exposure produces reactive oxygen and affects the stability of p53 and damages the DNA. Cells that are already genetically damaged, but not dead, may turn into cancer cells [6]. Exposure to radon radiation can also affect the process of forming $\operatorname{IgA}$ in the saliva. The saliva $\operatorname{IgA}$ content can prevent the occurrence of dental caries. The saliva of patients with high IgA levels shows a higher level of resistance against Streptococcus mutans [7].

Evaluating salivary flow factors for individuals at risk for caries may be recommended by the dentists in planning treatment [8]. The caries incidence in an area is obtained by calculating the Decayed, Missing, and Filled Teeth (DMF-T) index using the World Health Organization's (WHO) 1987 criteria.

So far, there has been no research into the relationship of saliva flow in people living in high radon areas with their incidence of caries. The researcher was interested to discover the relationship of saliva flow to the incidence of caries in a population in a high radon area and to compare it with that in a region with a low radon level.

\section{Methods}

Cross-sectional observational research was conducted for one month in 2017. Samples were obtained from 100 people, including 50 villagers from the Gunung Masigit village (a high radon content area) and 50 people from Cipatat village (a low radon content area), using the technique of consecutive sampling.

This research was approved by the Commission of Health Research Ethics, Faculty of Medicine, Padjadjaran University. Each participant signed an informed consent form to indicate their agreement to participate in the research.

\subsection{Inclusion Criteria}

Male or female residents in the age range 26-45 years old who had lived in the village from birth or for at least 20 years.

\subsection{Exclusion Criteria}

People with systemic diseases (such as diabetes mellitus, Stevens Johnson Syndrome, and hypertension), active smokers, and those taking drugs that result in a decreased salivary flow rate were excluded. Residents who used orthodontic appliances and prostheses as well as those undergoing radiation therapy were also excluded from the research. 


\subsection{Measurement of Saliva Flow Rate and DMF-T Index}

Tools and materials used in this research were measuring cylinders, a funnel, stopwatch, glass mouth, explorer, and a WHO Probe. Non-stimulated saliva was collected in the morning. Prior to saliva collection, participants were asked to brush their teeth one hour before the measurements were taken. Participants were asked to collect saliva in their mouths for five minutes in an upright position, sitting comfortably and feeling relaxed. Saliva that accumulated in the mouth was then spat out into a beaker and the volume was measured. After that, the saliva flow rate was calculated by dividing the saliva volume by the length of the collection period.

Assessment of the DMF-T index was performed by using the mouth, explorer and WHO Probe, and by examining the teeth of each participant for decay, missing or filled teeth. The caries incidence of each village was then calculated. This study is done by post graduated dental student than calibrated by professional.

\subsection{Data analysis}

The data from the research were calculated and analyzed by using the independent samples T-test and Pearson's correlation coefficient to determine the relationship of the saliva flow rate to the incidence of caries and to compare the data for the populations from the low and high radon regions.

\section{Results}

The average saliva flow rate of the population in the area with the high radon level, Gunung Masigit village, was $0.231 \mathrm{ml} / \mathrm{min}$, with a standard deviation of 0.113 , a minimum value of 0.025 and a maximum value equal to 0.5 . The caries incidence for this group was 11.84 (Table 1).

Table 1. Saliva Flow Rate and Caries Incidence

\begin{tabular}{|c|c|c|c|c|}
\hline & \multicolumn{2}{|c|}{ Cipatat } & \multicolumn{2}{|c|}{ Masigit } \\
\hline & Saliva Flow Rate & DMF-T & Saliva Flow Rate & DMF-T \\
\hline Mean & 0.467 & \multirow{4}{*}{7.600} & 0.231 & \multirow{4}{*}{11.840} \\
\hline Min & 0.100 & & 0.025 & \\
\hline Max & 1.200 & & 0.500 & \\
\hline Std.Dev & 0.243 & & 0.113 & \\
\hline
\end{tabular}

Table 1 also shows that the average saliva flow rate of the population in the area with a low radon content, Cipatat village, was $0.467 \mathrm{ml} / \mathrm{min}$, with a standard deviation of 0.243 , a minimum value of 0.100 , and a maximum value of 1.20 . The incidence of caries in Cipitat village was 7.6. The statistical differences in the population saliva flow rates between Cipatat village and Gunung Masigit village are shown in Table 2.

Table 2. Differences in Saliva Flow Rate for Cipatat village and Gunung Masigit village

\begin{tabular}{|c|c|c|c|c|c|}
\hline Saliva Flow Rate & Mean & T-count & P-Value & T-table & Notes \\
\hline Cipatat & 0.467 & 6.222 & 0.000 & 1.984 & $\begin{array}{l}\text { significant } \\
\text { difference }\end{array}$ \\
\hline Gunung Masigit & 0.231 & & &
\end{tabular}


Table 2 shows the statistical results from the independent T-test for the difference in saliva flow rate in Cipatat village and Gunung Masigit village. From the results of the data processing, the $T$ value was 6.222 and the $p$-value 0.000 . Since the p-value was less than $5 \%(0.000)$ and the T-count was greater than the T-table $(6.222>1.984)$, there was a significant difference between the saliva flow rate in Cipatat village and that in Gunung Masigit village.

The difference in the incidence of caries in the populations of Cipatat village and Gunung Masigit village are shown in Table 3.

Table 3. Differences in Caries Incidence in Cipatat village and Gunung Masigit village

\begin{tabular}{|c|c|c|c|c|c|}
\hline DMF-T & Mean & T-Count & p-Value & T-table & Notes \\
\hline Cipatat & 7.60 & 4.195 & 0.000 & 1.984 & $\begin{array}{c}\text { significant } \\
\text { difference }\end{array}$ \\
\hline Gunung Masigit & 11.84 & & &
\end{tabular}

It can be seen from Table 3 that there were differences in the incidence of caries in Cipatat and Gunung Masigit villages. The calculation of the independent T-test results gave a $T$ count value of 4.195 and a $p$-value of 0.000 . Since the $p$-value value was less than 5\% (0.000) and the T-count greater than the T-table (4.195> 1.984), there was a significant difference between the incidence of caries in Cipatat village and in Gunung Masigit village.

The relation of saliva flow rate to caries incidence in the populations of Cipatat village and Gunung Masigit village can be seen in Table 4.

Table 4. The Relationship of Saliva Flow Rate to Caries Incidence

\begin{tabular}{|c|c|c|c|c|}
\hline Village & Variable & R & Notes & p-value \\
\hline Cipatat & \multirow{2}{*}{ Saliva Flow Rate and Caries Prevalence } & -0.291 & Low & 0.040 \\
\cline { 3 - 5 } & & -0.043 & Very Low & 0.768 \\
\hline
\end{tabular}

Table 4 shows that the correlation coefficient between saliva flow rate and caries incidence in Cipatat village is -0.291 . This indicates a low correlation between salivary flow rate and incidence of caries. From the results of data processing, the pvalue was identified as 0,04 . When compared with the significance value of 0.05 , because (0.040) it appears that there is a relationship between saliva flow rate and caries incidence in Cipatat village. It is a negative relationship meaning that if the salivary flow rate is higher, the incidence of caries will be lower.

Table 4 also shows that the correlation coefficient between saliva flow rate and caries incidence for Gunung Masigit village is -0.043 . This indicates a very low association between salivary flow rate and incidence of caries. The results of the data processing give the $\mathrm{p}$-value as equal to 0,768 . When compared to the significance value of 0.05 , because $(0.768)$, there is no relationship between saliva flow rate and incidence of caries in Gunung Masigit village. 


\section{Discussion}

Saliva is the secretion of the salivary glands, which constantly wets the teeth and oral mucosa. The results show that the saliva flow rate of the population of Cipatat village was higher than that of the population of Gunung Masigit village. The average saliva flow rate in Cipatat Village was $0.467 \mathrm{ml} / \mathrm{min}$, while the mean salivary flow rate in Gunung Masigit village was only $0.231 \mathrm{ml} / \mathrm{min}$ (Table 1). The lower saliva flow rate in Gunung Masigit village (a high radon content area) may be caused by the radon radiation originating from the drinking water sources of the residents causing impaired salivary gland function. Decreased saliva production not only causes severe damage and affects the health of the oral cavity, but it also affects the quality of life of the sufferer [9]. According to Mojabi et al. (2007), a high incidence of dental caries, oral mucositis, dispagia, oral infection and taste disorders is experienced by people who have a decreased salivary flow rate [10].

The effect of radiation in the oral cavity is to damage the parenchymal component of the radiosensitive salivary glands. Components of damaged parenchyma will cause the gland to become fibrosis so that salivary secretion decreases [11].

According to Edgar et al. (2013), saliva is a useful diagnostic fluid by which to measure a person's susceptibility to caries events [9].

Radon is one of the most widely dispersed radionuclides that can affect the incidence of caries. The results of this research showed that the level of caries in the population living in the area of low radon levels, Cipatat village, was lower than that in the population from the area of high radon levels, Gunung Masigit village. Spivak et al. (2004) showed significant differences in DMF-T values in Ukrainian regions with either a high or a low radionuclide level [12].

The DMF-T index in the 50 residents of Cipatat village, with radon levels of 16.6 $\pm 24 \mathrm{~Bq} / \mathrm{m}^{3}$, and $26-45$ years old, was 7.6 (Table 1); while in the population of Gunung Masigit village, with radon levels of $24.8 \pm 29 \mathrm{~Bq} / \mathrm{m}^{3}$, and in a sample of the same age, the DMF-T index was 11.84 (Table 1). Based on WHO criteria, the DMF-T value for Cipatat village is moderate. Table 1 shows that, on average, in every mouth of the population there are 7 teeth either with caries, extractions due to caries, or teeth patched for caries in anterior and posterior of the teeth, whereas in Gunung Masigit village the DMF-T index is higher. Here, the DMF-T number of 11.84 means that, on average, in each mouth there are 11 teeth either with caries, extracted due to caries, or patched due that would be found in incisive, premolar or molar of the teeth.

The high occurrence of caries in areas containing high levels of radionuclides is caused by prolonged radiation resulting from the daily consumption of local food and contaminated water and the continuous radiation of natural radionuclides contained in local buildings and rocks [12].

Radiation therapy may also exert direct effects on the teeth, including changes in the crystalline structure, dentinoenamel junction, acid solubility of enamel, and enamel and dentin microhardness. Radiation affects the micro-morphological structures of enamel and dentin accompanied by reduced dentin microhardness. Together, those changes might increase the risk of radiation caries [13]. 
Radon in low doses can increase the enzyme superoxide dismutase (SOD). The function of the SOD enzyme is as an antioxidant to free radicals because it can activate the body's defense mechanism and neutralize free radicals [14].

The results of this research showed that the highest DMF-T values were found in the posterior teeth and the least in the anterior teeth, whereas in cases of caries caused by radiation, tooth decay is found in almost all teeth. Radiation caries is caused by a disruption of the salivary gland function causing decreased IgA so that bacteria accumulate faster and diminish the self-cleansing ability of the oral cavity [15].

Limitations in this study are in controlling environmental factors that may affect salivary flow rate and the process of caries occurrence. Several factors affecting salivary flow rate and caries process that cannot be controlled are the behavioral factors of local people related to maintaining healthy teeth and mouth, technique and time of brushing and healthy lifestyle. Another environmental factor that cannot be controlled is the condition of the drinking water source of the population that can be contaminated by other elements or minerals.

\section{Conclusions}

From the results of this research it can be concluded that there is no significant relationship between salivary flow rate and incidence of caries in the residents of an area with high radon levels. The salivary flow rate of residents in the area with a high radon concentration was lower than the salivary flow rate in the area with a low radon concentration. The prevalence of dental caries in the population in the high radon concentration area was higher than the prevalence of caries in the low radon concentration area.

\section{Acknowledgment}

Several people played an important role in the completion of this research. First, we would like to thank to Dr. Nina Djustiana, drg., M. Kes, as Dean of the Faculty of Dentistry, Universitas Padjadjaran. We also would like to thank the Public Health Office of Kabupaten Bandung Barat, Puskesmas Cipatat and Puskesmas Gunung Masigit for their help and assistance during this research.

\section{References}

1. Stookey GK. The effect of saliva on dental caries. J Am Dent Assoc. 2008;139:11S-7S.

2. Banderas-Tarabay JA, Zacarías-D'Oleire IG, Garduño-Estrada R, Aceves-Luna E, González-Begné M. Electrophoretic analysis of whole saliva and prevalence of dental caries. A study in Mexican dental students. Arch Med Sci. 2002 Sep 1;33(5):499-505.

3. Thompson. R.E. Encyclopedia of Toxicology. Third Edition. 2014:46-50.

4. Alatas Z. Efek Kesehatan Pajanan Radiasi Dosis Rendah. Cermin Dunia Kedokteran. 2007; 154:17-23.

5. Hamzah Z, Saat A. Radon dan Pengaruhnya Terhadap Persekitaran Kehidupan Manusia. 2004. Avalable at: https://www.researchgate.net/publication/242203049

6. Field RW. Radon: an overview of health effects. 2011:745-52. 
7. Hara AT, Zero DT. The caries environment: saliva, pellicle, diet, and hard tissue ultrastructure. Dent Clin. 2010;54(3):455-67.

8. Gopinath V, Arzreanne AR. Saliva as a diagnostic tool for assessment of dental caries. Arch Orofac Sci. 2006; 1:57-9.

9. Edgar M; C. Dawes; D. O' Mullane. Saliva and Oral Health Fourth Edition. London: BDI; 2013.

10. Mojabi KB, Esfahani M, Hashemi HJ. Evaluation of unstimulated salivary flow rate and oral symptoms in menopausal women. J Dent (Tehran).2007;4(3):103-6.

11. Ongole, R, Praveen, B.N. Textbook of Oral Medicine, Oral Diagnosis and Oral Radiology. Second Edition. New Delhi: Elsevier; 2013.

12. Spivak K, Hayes C, Maguire JH. Caries prevalence, oral health behavior, and attitudes in children residing in radiation-contaminated and-noncontaminated towns in Ukraine. Community Dent Oral Epidemiol. 2004 Feb 1;32(1):1-9.

13. Gonçalves LM, Palma-Dibb RG, Paula-Silva FW, de Oliveira HF, Nelson-Filho P, da Silva LA, de Queiroz AM. Radiation therapy alters microhardness and microstructure of enamel and dentin of permanent human teeth. J Dent. 2014 Aug 1;42(8):986-92.

14. Zdrojewicz Z, Strzelczyk J. Radon treatment controversy. Dose-Response. 2006;4(2): 106-18.

15. DeLong L, Burkhart N. General and oral pathology for the dental hygienist. Lippincott Williams \& Wilkins; 2013 Feb 25. 